Adamiak S., Walczak D. (2014). Catholic social teaching, sustainable development and social solidarism in the context of social security. Copernican Journal of Finance \& Accounting, 3(1), 9-18. http://dx.doi.org/10.12775/CJFA.2014.001

\author{
Stanistaw Adamiak* \\ Pontifical Gregorian University
}

\author{
Damian WaLCzaK ${ }^{* *}$ \\ Nicolaus Copernicus University
}

\title{
CATHOLIC SOCIAL TEACHING, SUSTAINABLE DEVELOPMENT AND SOCIAL SOLIDARISM IN THE CONTEXT OF SOCIAL SECURITY
}

Key word: social security, Catholic social teaching, social solidarity, sustainable development.

J E L Classification: A12, A13, Z12.

\begin{abstract}
Nowadays, opposite to what could be observed at the end of the nineteenth century, people are more focused on creating larger societies rather than sets of alienated individuals. Certainly, there are many factors that cause this kind of trend. The factors may include social determinants known as Catholic social teaching, social solidarism and sustainable growth.

Each of the above factors refers to the three methods of social security, whose aim is to protect citizens against the threat of unsatisfied basic needs, socially recognized as valid. Catholic social teaching, social solidarism and sustainable growth refer both to obliging the state to help people who are facing a situation of unsatisfied basic needs
\end{abstract}

Date of submission: February 12, 2014; date of acceptance: March 23, 2014.

* Contact information: stasadam@o2.pl, Faculty of History and Cultural Heritage of the Church, Pontifical Gregorian University, Piazza della Pilotta 4, 00187 Rome.

** Contact information: dwalczak@umk.pl, Department of Finance Management, Faculty of Economic Sciences and Management, Nicolaus Copernicus University, Gagarina 13a, 87-100 Toruń, Poland, phone: 566114634. 
(do not allow the possibility of leaving the individual alone - the procurement method) and to indicating everyone the necessity of self-protection that reaches above the minimum guaranteed by the state (the insurance method). Also, they indicate the possibility (necessity) of functioning in society a kind of support provided to persons in need from voluntary payments (institutions or individuals - the philanthropic method).

\section{KATOLICKA NAUKA SPOŁECZNA, ROZWÓJ ZRÓWNOWAŻONY ORAZ SOLIDARYZM SPO- ŁECZNY W KONTEKŚCIE ZABEZPIECZENIA SPOŁECZNEGO}

Słowa kluczowe: zabezpieczenie społeczne, Katolicka nauka społeczna, solidaryzm społeczny, rozwój zrównoważony.

Klasyfikacja J E L: A12, A13, Z12.

Abstrakt: Obecnie, w przeciwieństwie do tego co miało miejsce jeszcze do końca XIX wieku, ludzie w większym zakresie tworzą społeczeństwa, niż zbiory pojedynczych, wyalienowanych jednostek. Zapewne jest wiele czynników powodujących tego rodzaju tendencje. Czynnikami takimi mogą być uwarunkowania społeczne określane jako: katolicka nauka społeczna, solidaryzm społeczny lub wzrost zrównoważony.

Każdy z ww. czynników odwołuje się do trzech metod zabezpieczenia społecznego, którego celem jest zabezpieczenie obywateli przed groźbą niezaspokojenia podstawowych potrzeb, społecznie uznanych za ważne. Katolicka nauka społeczna, solidaryzm społeczny oraz wzrost zrównoważony odwołują się zarówno do zobligowania państwa do pomocy osobom znajdującym się w sytuacji niezaspokojenia podstawowych potrzeb (nie dopuszczają możliwości pozostawienia jednostki samej sobie - metoda zabezpieczeniowa), jak i do wskazywania każdemu człowiekowi konieczności samodzielnego zabezpieczenia powyżej minimum gwarantowanego przez państwo (metoda ubezpieczeniowa), ale także wskazują na możliwość (konieczność) funkcjonowania w społeczeństwie wsparcia, ze strony instytucji charytatywnych (lub osób fizycznych), adresowanego do osób potrzebujących (metoda filantropijna).

Translated by Damian Walczak

\section{IIIITRODUCTION}

Sustainable development, Catholic social teaching and social solidarism ${ }^{1}$ relate to economics as a science dealing with research on the economic activity of people. They affect, however, a different sphere of human functioning. Catholic social teaching seeks to answer the question about the meaning of this activity in the context of social order (Klimczak 2012, 23), and sustainable deve-

${ }^{1}$ What is meant here is 'secular' social solidarism, referred to also by non-believers, and not the one resulting from Catholic social teaching. 'Secular' solidarism, unlike Catholic social teaching, concerns (on the part of beneficiaries) not only people but also other entities such as: regions, countries, etc. 
lopment answers the question on how to manage resources so as not to limit the developmental opportunities for future generations (Redclift 2009, 35-36; Walczak 2013, 328-329, 335), whereas solidarism means the action of people within the community of interests with various social groups and strata (Colcord 1928, 577-579).

Each of these spheres (social order, the development of future generations, the community of interests) is related to social security, which since the end of the nineteenth century, that is, from the beginning of its institutionalized forms, has raised a lot of controversy. On the one hand, there are the public's expectations for the systematic increase in public sector spending, including social security (Wagner's Law); on the other hand, financial problems of individual countries and the demographic decline limit these expenses (Henrekson 1993, 406-408; Bera, Walczak 2012, 115-116; Kawiński, Stańko, Rutecka 2012, 1-4).

\section{THE RESEARCH METHODOLOGY AND THE COURSE OF THE RESEARCH PROCESS}

The work includes a critical analysis of literature in the area of Catholic social teaching, social solidarism and sustainable development. In its second part, the relations holding between those areas of social security are scrutinized.

The aim of the study is to analyze the relations between solidarism, sustainable development, and Catholic social teaching in the context of social security.

\section{BASIC TERMINOLOGY - SUSTAINABLE DEVELOPMENT, SOCIAL SOLIDARISM, AND CATHOLIC SOCIAL TEACHING}

Sustainable development is the development that meets the needs of the present generation and can be met without limiting the ability of future generations to meet their own needs (United Nations 1987). The Sustainable Development Strategy of the European Union was approved in May 2001 by the European Council in Gothenburg, and then was renewed in June 2006. It defines the way in which the EU should meet effectively the challenges of this development. This document is distinctive among the fundamental principles of sustainable development in its approach to internal and intergenerational solidarism and it mentions the need for global solidarism (Council 2006).

Among various aspects of sustainable development we can indicate the environmental, economic and social ones. Sustainable development in the eco- 
nomic (among other things, a balanced budget) and social (including equality of income, poverty reduction) aspects is based on social solidarism (Kates, Parris, Leiserowitz 2005, 9-20). At the same time an increase in income inequality (the social aspect) hinders the growth of economic prosperity (the economic aspect) (Talberth, Cobb, Slattery 2006, 8; Dacheux, Goujon 2011, 205-215).

Social security (implemented by the State or by an individual forethought) is responsible for both social and economic aspects of sustainable development, since it impacts the financial situation of the present and future generations.

The Treaty of Lisbon (officially - Treaty of Lisbon amending the Treaty on European Union and the Treaty establishing the European Community, signed at Lisbon, 13 December 2007) refers repeatedly to the idea of social solidarism. Article I-2 (The Union's values) mentioned that 'These values are common to the Member States in the society based on pluralism, non-discrimination, tolerance, justice, solidarism and equality between women and men'. However, Article I-3 says that the Union combats social exclusion and discrimination, and promotes social justice and security, equality between women and men, solidarism between generations and protection of the rights of the child', and, in addition, it 'supports the economic, social and territorial cohesion and solidarism among Member States'.

Solidarism is thinking at the same time about the person and the community, which is created by a unit (group, society, country), and is combined with the mandatory actions of obligated entities, sometimes with altruism (Nicolaidis, Viehoff 2012, 28). Van Praag and Konijn (1983, 54-56) have identified solidarism as the basis for the functioning of social insurances, which, in turn, form the foundation of an efficient social security system.

Caro $(1931,9-10)$ states that 'the individual in a society that is based on the principles of solidarism serves the general good, but the state or society serve the good of units. In the activity of a socialized individual (...) the sake of public interest dominates, however, at the same time this individual is the goal in itself and has the right to care about his own good, without exceeding reasonable boundaries. In this way, solidarism represents the direction that in a higher synthesis combines the advantages of economic liberalism and socialism. Caro $(1931,9)$ also stresses that 'Cooperation, not competition, (...) is the slogan of solidarism.'

Social solidarism is stipulated by the Constitution of the Republic of Poland, according to which all are obliged to 'preserve the inherent human dignity, the right to liberty and obligation of solidarity with others' (from the Preamble), 
and the social market economy is based on economic freedom, private ownership, and solidarism, dialogue and cooperation between social partners forms the basis of the political system (Article 20). Further, it can be indicated that the principle of solidarism is one of the fundamental freedoms and rights of every human being, which is not subject to limitation, is not listed within the range of permissible restrictions on the exercise of constitutional rights and freedoms in Article 31, paragraph 3 (the Constitution of the Republic of Poland).

Clearly, social security is part of the essence of social solidarism through intergenerational solidarism, or through the concern of the community for the individual's interest.

In relation to solidarism Catholic social teaching is much alike. It objects statism and excessive concentration of responsibilities and resources in the hands of the state (which resulted from the logic of socialism) and it also opposes unlimited liberalism (Adamiak, Chojnacka, Walczak 2013, 16).

Key elements of the Catholic social teaching have been enunciated in the socalled social encyclicals of the popes. One of the most important of them was „Populorum progressio” („On the Development of the Peoples”), issued by Paul VI in 1967, where the necessity of the progress of the societies and the compatibility of such progress with the Catholic doctrine was stressed. The importance of this document was underlined in 2009 by Benedict XVI, who explained that „Paul VI had an articulated vision of development. He understood the term to indicate the goal of rescuing peoples, first and foremost, from hunger, deprivation, endemic diseases and illiteracy" (Benedict XVI 2009, 21). However, „The economic development that Paul VI hoped to see was meant to produce real growth, of benefit to everyone and genuinely sustainable" (Benedict XVI $2009,21)$. Benedict XVI showed the interest of the Church in the sustainability of the economy particularly in the context of the fight with famine and providing food for entire population of the earth: "The problem of food insecurity needs to be addressed within a long-term perspective, eliminating the structural causes that give rise to it and promoting the agricultural development of poorer countries. This can be done by investing in rural infrastructures, irrigation systems, transport, organization of markets, and in the development and dissemination of agricultural technology that can make the best use of the human, natural and socio-economic resources that are more readily available at the local level, while guaranteeing their sustainability over the long term as well" (Benedict XVI 2009, 27). The admonishments of the pope went also against the certain forms of globalization that tend to exploit the poorer coun- 
tries without giving them adequate perspectives of the sustainable growth: „What should be avoided is a speculative use of financial resources that yields to the temptation of seeking only short-term profit, without regard for the longterm sustainability of the enterprise, its benefit to the real economy and attention to the advancement, in suitable and appropriate ways, of further economic initiatives in countries in need of development" (Benedict XVI 2009, 40).

The call to the self-restraint in consumer habitudes has been henceforth repeatedly expressed by Pope Francis. In his apostolic letter „Evangelii gaudium” (2013) he warned that "inordinate consumption” is a threat to the social fabric and eventually leads to the resource to violence; therefore "he conditions for a sustainable and peaceful development have not yet been adequately articulated and realized" (Francis 2013, 59-60).

The Catholic social doctrine has always tried to find an equilibrium between the concern for the whole society, especially for the weakest and poorest, and the respect for the human liberty, including the right to the private property. The problem was reassumed in 1987 by John Paul II: „It is necessary to state once more the characteristic principle of Christian social doctrine: the goods of this world are originally meant for all. The right to private property is valid and necessary, but it does not nullify the value of this principle. Private property, in fact, is under a "social mortgage," which means that it has an intrinsically social function, based upon and justified precisely by the principle of the universal destination of good" (John Paul II 1987, 42).

It is therefore clear that the creating sustainable forms of the development, which attempt to provide social security both for the poorest in the present and for the potential poor in the future, have a good theoretical basis, among others, in the Catholic social teaching, for which the social solidarity (including the inter-generational solidarity) is one of the most important tenets.

\section{SOCIAL SECURITY - RELATIONS THAT CONNECT SUSTAINABLE DEVELOPMENT, SOLIDARISM AND CATHOLIC SOCIAL TEACHING}

The element connecting the issues presented is social security, defined as 'the totality of measures and public actions (institutions), with the help of whose society tries to protect its citizens against the threat of unsatisfied basic needs, socially recognized as important' (Piotrowski 1966, 29). Man exposed to certa- 
in risks (needs) ${ }^{2}$ can count on solidarism with others within the same risk community. This community may be narrower (industry) or larger (nationwide) in nature. Within social security the following three basic methods of protection can be distinguished:

- the insurance method (benefits are financed by contributions from insured persons or by individual savings),

- the procurement method (benefits are financed from the state budget so by the community),

- the philanthropic method (help comes from the voluntary payments made by institutions or individuals).

Both Catholic social teaching, sustainable development, or solidarism within indicating the form of aid directed to specific people refer, directly or indirectly, to these methods of social security (Table 1).

Table 1. Methods of social security in the context of sustainable development, social solidarism and Catholic social teaching

\begin{tabular}{|c|c|c|c|c|}
\hline \multicolumn{2}{|c|}{ Specification } & Catholic & Sustainable & Social \\
\hline \multirow{3}{*}{ 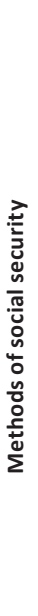 } & $\begin{array}{l}\text { The insurance } \\
\text { method }\end{array}$ & $\begin{array}{l}\text { Leaving the individual } \\
\text { independent (If the } \\
\text { individual needs abo- } \\
\text { ve-standard levels } \\
\text { of income from social } \\
\text { security, he needs to } \\
\text { provide it to and by } \\
\text { himself) }\end{array}$ & $\begin{array}{l}\text { The economic aspect } \\
\text { (a balanced budget } \\
\text { - the need to reduce } \\
\text { the spending on so- } \\
\text { cial security origina- } \\
\text { ting from the general } \\
\text { budget - everyone } \\
\text { has to think about } \\
\text { himself) }\end{array}$ & $\begin{array}{l}\text { Individual (as a member of the } \\
\text { community) cannot limit himself } \\
\text { to be protected only by the Com- } \\
\text { munity - cannot live at the expense } \\
\text { of others. He needs to do his } \\
\text { best to provide himself individual } \\
\text { security. }\end{array}$ \\
\hline & $\begin{array}{l}\text { The procurement } \\
\text { method }\end{array}$ & $\begin{array}{l}\text { Organized aid ought } \\
\text { to take a limited } \\
\text { form, but must } \\
\text { guarantee a certain } \\
\text { minimum level/relie- } \\
\text { ving poverty }\end{array}$ & $\begin{array}{l}\text { The social aspect } \\
\text { (the equality of } \\
\text { income/relieving } \\
\text { poverty) }\end{array}$ & $\begin{array}{l}\text { The natural community of interests } \\
\text { that links all members } \\
\text { (no one can be left alone). } \\
\text { In Poland solidarism constitutes } \\
\text { a fundamental right and freedom } \\
\text { of every person and is guaranteed } \\
\text { by the Constitution }\end{array}$ \\
\hline & $\begin{array}{l}\text { The philanthropic } \\
\text { method }\end{array}$ & $\begin{array}{l}\text { Christian charity/ } \\
\text { relieving poverty }\end{array}$ & $\begin{array}{l}\text { The social aspect (the } \\
\text { equality of income/ } \\
\text { relieving poverty) }\end{array}$ & Altruism \\
\hline
\end{tabular}

S o u r c e : elaborated by the author.

2 Social security risks include sickness, unemployment, old age, accidents at work and occupational diseases, maternity, invalidity, death, poverty. 
Social solidarism impacts sustainable growth both directly, through economic or social aspects, as well as indirectly through social security, which, in fact, is part of sustainable development. In this respect, solidarism should be considered in various dimensions, in the light of the intra and intergenerational, nationwide or intergroup solidarism. Catholic social teaching, as part of the doctrine of the Catholic Church with about 1.2 billion followers around the world, has an impact on both the idea of social solidarism and the concept of sustainable development. At the same time 'secular' solidarism over the years has affected the Catholic social doctrine, which could not be formed in isolation from the changing world (Figure 1).

Figure 1. Dependencies (impact) between Catholic social teaching, social solidarism and sustainable development

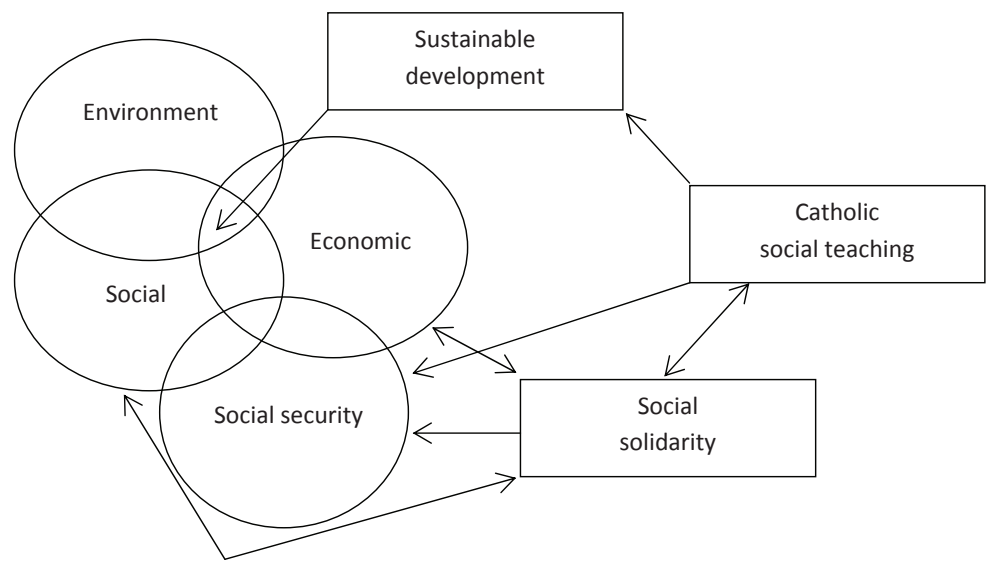

S o u r c e : elaborated by the author.

\section{ConCLUSIONS}

Solidarism requires that we should look at the man (unit) communally, but should not forget his role to be fulfilled. Similarly, Catholic social teaching and sustainable development assume the functioning of various subjects only within good community.

Therefore, sustainable development, which should be treated interdisciplinary is necessarily associated with social security and thus also with a social solidarism. This solidarism impacts two of the three elements of sustainable development. At the same time we cannot forget Catholic social teaching, which due 
to the secularization of Europe is becoming less appreciated, but by its concern about both the unit and the common good affects the shape of social security.

Over many thousands of years the stronger (economically or physically) used to defeat/eliminate the weaker, nowadays, no matter what we call the reason for this decision - within Catholic social teaching, social solidarism, and sustainable growth - the stronger helps the weaker. This aid may take the form of in-kind or material, refer to the present or the future. 'The Stronger', which can be depending on the method of social security, individual people, regions, nations or institutions, are to offer real help and not, as demonstrated by the frequent experience - strive for the elimination or annihilation of another entity.

\section{REFERENCES}

Adamiak S., Chojnacka E., Walczak D. (2013). Social security in Poland - cultural, historical and economical issues. Copernican Journal of Finance \& Accounting, vol. 2, no. 2. http://dx.doi.org/10.12775/CJFA.2013.013.

Benedict XVI (2009), Caritas in veritate.

Bera A., Walczak D. (2012). Problematyka wieku emerytalnego w modernizacji polskiego systemu emerytalnego. Wiadomości Ubezpieczeniowe, nr 1.

Caro L. (1931), Solidaryzm, Z zasiłku Funduszu Kultury Narodowej, Lwów.

Colcord J. C. (1928). Community of Interest as a Basis for Family Solidarity. Social Forces, vol. 6, no. 4. http://dx.doi.org/10.1093/sf/6.4.577.

Council of The European Union (2006), Review of the EU Sustainable Development Strategy (EU SDS) - Renewed Strategy, 10917/06, 26 June 2006.

Dacheux D., Goujon D. (2011). The solidarity economy: an alternative development strategy?. International Social Science Journal. Mar-Jun2011, vol. 62, issue 203/204. http://dx.doi.org/10.1111/j.1468-2451.2011.01804.x.

Francis (2013), Evangelii gaudium.

Henrekson M. (1993). Wagner's Law: A Spurious Relationship?. Public Finance, vol. 48, no 2 .

John Paul II (1987), Sollicitudo rei socialis.

Kates R.W., Parris T.M., Leiserowitz A.A. (2005). What is sustainable development? goals, indicators, values, and practice. Environment: Science and Policy for Sustainable Development, vol. 47, no. 3.

Kawiński M., Stańko D., Rutecka J. (2012). Protection mechanisms in the old-age pension systems of the CEE countries. Journal of Pension Economics and Finance, vol. 14, issue 4. http://dx.doi.org/10.1017/S147474721200008X.

Klimczak B. (2012). Trudne związki katolickiej nauki społecznej i ekonomii. Annales. Etyka w życiu gospodarczym, vol. 15. 
Nicolaïdis K., Viehoff J. (2012), The Choice for Sustainable Solidarity in Post-Crisis Europe, [in:] G. Bajnai et al. (ed.), Solidarity: For Sale? The Social Dimension of the New European Economic Governances, Europe in Dialogue 01.

Piotrowski J. (1966), Zabezpieczenie społeczne. Problematyka i metody, Książka i Wiedza, Warszawa.

Redclift, M. R. (2009), Rozwój zrównoważony (1987-2005) - oksymoron czasu dorastania, Sustainable Development (1987-2005) - an Oxymoron Comes of Age, Problemy Ekorozwoju, vol. 4, no 1. http://dx.doi.org/10.1002/sd.281.

Talberth J., Cobb C., Slattery N., (2006), The Genuine Progress Indicator 2006. A Tool for Sustainable Development, Oakland.

The Constitution of the Republic of Poland of April 2, 1997 (Dz.U. 1997 nr 78 poz. 483).

Treaty of Lisbon amending the Treaty on European Union and the Treaty establishing the European Community, signed at Lisbon, 13 December 2007 (Dz.U. 2009 nr 203 poz. 1569).

United Nations (1987), Report of the World Commission on Environment and Development, Our Common Future.

Van Praag B. M., Konijn, P. A. (1983). Viewpoint: solidarity and Social Security. Challenge, vol. 26, no. 3 .

Walczak D. (2013), Środki z UE w gospodarstwach rolnych jako element strategii zrównoważonego rozwoju obszarów wiejskich w Polsce, Prace Naukowe Uniwersytetu Ekonomicznego we Wrocławiu, nr 297. 